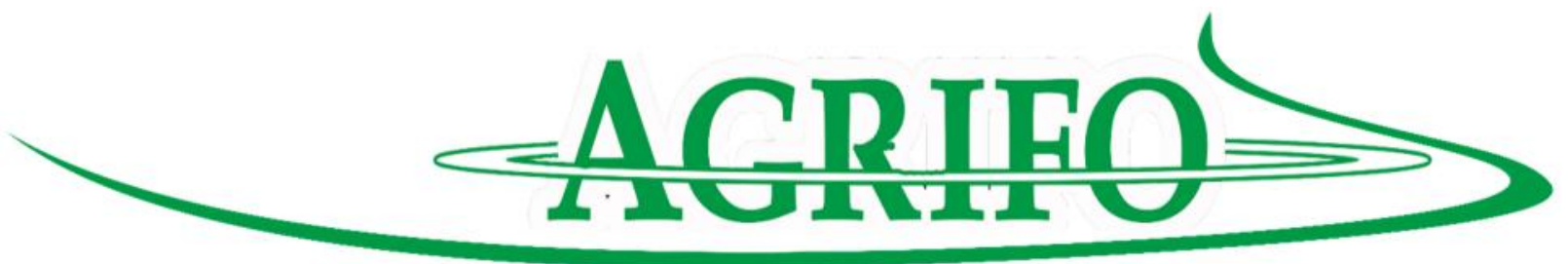

\title{
ANALISIS DAYA SAING EKSPOR KOMODITAS UDANG INDONESIA
}

Mufa'ah dan Mardiyah Hayati

Prodi Agribisnis Fakultas Pertanian Universitas Trunojoyo Madura

Email: mardiyah@trunojoyo.ac.id

\begin{abstract}
This study was conducted to determine the competitiveness and performance of Indonesia to shrimp export commodities also determine the factors that affect the level of competitiveness so as to be a strategy to improve the competitiveness of Indonesian shrimp commodity in the international market. The data that used in this study are primary and secondary data. Tools of analysis used in this study are Revelead Comparative Advantege (RCA), Literacy Test, and SWOT analysis (Strength, Weakness, Opportunity, and Threat). Results of the analysis showed that Indonesian shrimp export commodities have strong competitiveness (RCA>1) and an increase in performance between the current years with the previous year (RCA index> 1). While the most influential factor is worker, Land, governance program, number of shrimp production, capital, diversivication of product, Surroundings, human resource, basic materials, seed, demand, price, competitor, standart dan quality.
\end{abstract}

Keyword: competitiveness, analysis RCA, analysis SWOT, performance

\section{PENDAHULUAN}

Indonesia merupakan negara agraris dengan berbagai sub sektor yang dimiliki. Salah satunya yaitu sektor perikanan yang berpotensi tinggi dalam menggerakkan perekonomian nasional. Kontribusi sektor perikanan terhadap PDB sebesar 3,2 persen dari total PDB tahun 2013 yaitu 2.210,06 trilliun serta mampu menjadi penyedia lapangan kerja dan sumber devisa negara. Perikanan Indonesia menghasilkan berbagai jenis komoditas, namun tidak semua komoditas mampu diperdagangkan di pasar dunia. Volume dan nilai ekspor perikanan Indonesia mengalami fluktuatif pada tiga tahun terakhir (tabel 1). 
Tabel 1 Kontribusi ekspor sub sektor perikanan pada 2010-2012

\begin{tabular}{llll}
\hline & 2010 & 2011 & 2012 \\
\hline Volume (Ton) & & & \\
- Ekspor & $28,768,085$ & $29,959,565$ & $35,263,290$ \\
- Impor & $16,874,998$ & $22,917,892$ & $20,889,174$ \\
- Neraca & $11,898,087$ & $7,041,764$ & $14,374,116$ \\
Nilai (USD 000) & & & \\
- Ekspor & $32,522,974$ & $43,365,004$ & $38,277,481$ \\
- Impor & $13,983,327$ & $20,598,660$ & $15,071,682$ \\
- Neraca & $18,539,647$ & $22,766,344$ & $23,169,799$
\end{tabular}

Sumber: Statistik Makro, 2013

Terdapat 6 provinsi di Indonesia yang memberikan kontribusi ekspor hasil perikanan tertinggi, yaitu Jawa Timur sebesar 352.839 ton atau mengalami peningkatan sebesar 3,24 persen, DKI Jakarta sebesar 274.762 ton atau meningkat sebesar 4,29 persen, Maluku sebesar 187.143 ton atau meningkat sebesar 28,24 persen,
Sulawesi Selatan sebesar 91.125 ton atau meningkat sebesar 1,19 persen, Sumatra Utara sebesar 77.975 ton atau meningkat sebesar 10,33 persen, dan Papua Barat sebesar 42.844 atau meningkat 15,84 persen (Statistik Indonesia, 2012). Udang merupakan komoditas perikanan yang dilakukan ekspor ke pasar dunia. 
Tabel 2. Negara Tujuan Ekspor Udang Indonesia Tahun 2008-2012

\begin{tabular}{|c|c|c|c|c|c|}
\hline \multirow[b]{2}{*}{ Tahun } & \multicolumn{4}{|c|}{ Negara Tujuan } & \multirow[b]{2}{*}{ Total } \\
\hline & $\begin{array}{l}\text { Amerika } \\
\text { Serikat }\end{array}$ & Jepang & $\begin{array}{c}\text { Uni } \\
\text { Eropa }\end{array}$ & $\begin{array}{l}\text { Negara } \\
\text { Lainnya }\end{array}$ & \\
\hline \multicolumn{6}{|l|}{ Tahun 2008} \\
\hline Volume (Ton) & 80479 & 39582 & 26825 & 177855 & 324474 \\
\hline Nilai (US\$ 1000) & 550773 & 337681 & 26397 & 96306 & 1011157 \\
\hline \multicolumn{6}{|l|}{ Tahun 2009} \\
\hline Volume (Ton) & 63592 & 38528 & 23689 & 58180 & 183989 \\
\hline Nilai (US\$ 1000) & 426995 & 333656 & 146597 & 100833 & 1008081 \\
\hline \multicolumn{6}{|l|}{ Tahun 2010} \\
\hline Volume (Ton) & 58277 & 36712 & 13383 & 36720 & 145092 \\
\hline Nilai (US\$ 1000) & 443220 & 351402 & 110549 & 151228 & 1056399 \\
\hline \multicolumn{6}{|l|}{ Tahun 2011} \\
\hline Volume (Ton) & 68092 & 36605 & 16315 & 31041 & 154580 \\
\hline Nilai (US\$ 1000) & 572720 & 393266 & 136975 & 108585 & 1211546 \\
\hline \multicolumn{6}{|l|}{ Tahun 2012} \\
\hline Volume (Ton) & 72526 & 38541 & 16359 & 33524 & 160950 \\
\hline Nilai (US\$ 1000) & 590781 & 418447 & 145890 & 179302 & 1334420 \\
\hline
\end{tabular}

Sumber: Kementrian Kelautan dan Perikanan, 2013

Ekspor udang Indonesia flutuatif dipengaruhi oleh beberapa mengalami fluktuatif dari tahun 2008- faktor seperti adanya penetapan 2012 dengan pangsa pasar terbesar standart negara pengimpor, yaitu Amerika Serikat, Jepang, dan perlindungan konsumen negara Uni Eropa (Tabel 2). $\quad$ pengimpor, dan peningkatan kualitas Pergerakan volume dan nilai udang. ekspor udang Indonesia secara

Tabel 3 Produksi udang Indonesia tahun 2007-2012

\begin{tabular}{llll}
\hline \multirow{2}{*}{ Tahun } & \multicolumn{2}{c}{ Produksi } & \multirow{2}{*}{ Total Produksi } \\
\cline { 2 - 3 } & Tangkap & Budidaya & \\
\hline 2008 & 236.922 & 409.590 & 646.512 \\
2009 & 236.870 & 338.060 & 574.930 \\
2010 & 227.326 & 380.972 & 608.298 \\
2011 & 228.870 & 414.014 & 642.884 \\
2012 & 229.723 & 415.703 & 645.426 \\
\hline
\end{tabular}

Sumber: Kementrian Kelautan dan Perikanan, 2012 
Secara keseluruhan, produksi udang mengalami peningkatan pada lima tahun terakhir (Tabel 3). Akan tetapi, peningkatan tidak terjadi pada udang tangkap. Produksi yang dihasilkan udang tangkap mengalami penurunan pada tahun 2008-2010 dikarenakan adanya suku bunga, penyakit, serta masalah sosial keamanan yang terjadi di Indonesia. Saat ini, daya saing udang indonesia masih berada di bawah udang Vietnam dilihat dari harga jual serta kualitas pada udang. Trend tentang peralihan konsumsi masyarakat luar from red met to white meat memberikan dampak pada peningkatan jumlah permintaan udang di pasar dunia.

Namun, Indonesia masih belum bisa memenuhi permintaan pasar dunia secara keseluruhan. Melihat kondisi tersebut perlu dilakukan adanya penelitian untuk mengetahui daya saing udang di pasar internasional, sehingga dapat dirumuskan strategi apa yang akan digunakan guna meningkatkan daya saing udang yang memberi dampak pada peningkatan sumber devisa negara. Untuk mengetahui adanya daya saing dapat dilihat pada kemampuan suatu negara dalam bersaing dengan keunggulan yang dimilikinya (Apridar, 2009). Pengukuran bisa dilakukan dengan metode RCA yang dapat menujukkan adanya tingkat daya saing serta kinerja ekspor.

Terdapat beberapa faktor yang mempengaruhi tingkat daya saing ekspor udang indonesia yaitu:

1. Jumlah tenaga kerja, menjadi pelaku utama dalam melakukan usaha tani udang serta mempengaruhi tingkat keberhasilan suatu usaha.

2. Lahan, salah satu input yang berpengaruh terhadap jumlah produksi.

3. Program pemerintah, berperan dalam meningkatkan produksi serta subsidi untuk menghasilkan udang berkualitas.

4. Jumlah produksi, sebagai dasar utama bagi negara untuk melakukan ekspor ke pasar dunia.

5. Modal, sumber daya yang harus dimiliki oleh pelaku usahatani.

6. Diversifikasi produk, proses yang muncul karena ide untuk 
memberikan nilai tambah suatu produk.

7. Lingkungan, sebagai tempat berkembangnya suatu usaha.

8. Pakan, faktor pembatas dalam kegiatan produksi secara intensif

9. Benih, kunci keberhasilan dalam pencapaian target produksi yang telah ditetapkan oleh pemerintah

10. Permintaan, mempengaruhi tinggi rendahnya daya saing terhadap suatu komoditas

11. Harga, faktor yang mempengaruhi tingkat persaingan dan dipengaruhi oleh kurs valuta asing (dollar).

12. Pesaing, mendorong sutu negara untuk meningkatkan daya saing melalui strategi yang dilakukan

13. Standart dan Kualitas, ukuran untuk meningkatkan kualitas yang dimiliki melalui standart yang ditetapkan.

Tujuan dari penelitian ini yaitu untuk mengetahui tingkat daya saing yang dimiliki serta faktor-faktor yang mempengaruhi daya saing udang sehingga mampu dibentuk strategi untuk meningkatkan daya saing udang Indonesia.

\section{METODE PENELITIAN}

Lokasi penelitian dilakukan secara purposive sampling yaitu di Indonesia yang merupakan negara terbesar keduayang melakukan ekspor udang.

Data yang digunakan dalam penelitian ini adalah data primer dan data sekunder. Data primer digunakan untuk penentuan startegi yang akan diambil dari dinas melalui penyebaran kuisioner pada dinas terkait di jawa timur (disperindag, dinas perikanan, dan ahli bidang perikanan). Sedangkan data sekunder digunakan untuk mengetahui tingkat daya saing serta faktor-faktor yang mempengaruhi daya saing udang Indonesia yang meliputi data BPS, Kmentrian Perikanan dan Kelautan, Un Comtrade, FAO, dll.

Terdapat tiga metode analisis yang digunakan dalam penelitian ini. Pertama, analisis RCA untuk mengetahu tingkat daya saing komoditas udang, secara sistematis dapat ditulis sebagai berikut:

$$
\mathrm{RCA}_{\mathrm{c}}=\frac{X c / X c t}{X w / X w t}
$$


Dimana:

RCA $_{C}$ : Nilai keunggulan komparatif komoditas udang

$X_{c} \quad$ : Nilai ekspor komoditas udang indonesia pada tahun tertentu

Xct : Nilai total ekspor komoditas

Indonesia di tahun tertentu

Xwc : Nilai ekspor dunia komoditas udang di tahun tertentu

Xwt : Nilai total ekspor dunia komoditas di tahun tertentu

Perbandingan nilai RCA sekarang dengan nilai RCA tahun sebelumnya dapat dihitung dengan menggunakan indeks RCA, dimana rumus indeks RCA adalah:

Indeks RCA $=\frac{R C A t}{R C A t-1}(2)$

Keterangan:

$\mathrm{RCA}_{\mathrm{t}}=$ Nilai RCA udang pada tahun tertentu
$\mathrm{RCA}_{\mathrm{t}-1}=$ Nilai RCA udang pada tahun sebelumnya

$t \quad=2007, \ldots ., 2011$

Kedua, digunakan uji literasi berdasarkan penelitian terdahulu dan teori-teori (Wibowo, 2010). Dan ketiga, analisis SWOT untuk pembentukan strategi dengan melihat faktor internal dan eksternal daya saing udang Indonesia.

\section{HASIL DAN PEMBAHASAN}

Daya Saing Udang Indonesia

Untuk mengetahui daya saing ekspor udang dilakukan analisis RCA. Pada analisis RCA diperoleh nilai RCA yang menujukkan adanya daya saing suatu komoditas dan Indeks RCA yang menunjukkan adanya perubahan kinerja ekspor terhadap komoditas udang. Berikut hasil analisis RCA komoditas udang.

Tabel 4 Hasil perhitungan nilai RCA dan Indeks RCA

\begin{tabular}{lll}
\hline Tahun & Nilai RCA & Indeks RCA \\
\hline 2008 & 13,62 & - \\
2009 & 11,46 & 0,84 \\
2010 & 8,67 & 0,76 \\
2011 & 8,01 & 0,92 \\
2012 & 12,24 & 1,53
\end{tabular}

Sumber: Data Sekunder Diolah, 2012 
Pada tabel 4 menujukkan adanya daya saing yang kuat karena nilai RCA $>1$, sedangkan indeks RCA mengalami peningkatan yang menujukkan adanya peningkatan kinerja ekspor udang antara tahun sekarang dengan tahun sebelumnya. Namun, terjadi penurunan pada nilai RCA, penyebab penurunan tersebut antara lain menurunnya volume permintaan udang beku oleh negara pengimpor, adanya penolakan udang Indonesia oleh negara pengimpor sebagai akibat penggunaan antibiotik, tinggi rendahnya nilai GDP suatu negara, serta adanya batasan dan aturan yang ditetapkan ole negara pengimpor. Rata-rata indeks RCA mengalami peningkatan yang menujukkan adanya kemampuan udang Indonesia dalam memenuhi permintaan udang di pasar dunia. Saat ini, indonesia mampu memenuhi permintaan udang sebanyak 10,8 persen, sedangkan sisanya 89,2 persen dipenuhi dari negara pengekspor udang lainnya.
Faktor yang Mempengaruhi Tingkat Daya Saing Komoditas Udang Indonesia

Terdapat beberapa faktor yang mampu mempengaruhi daya saing ekspor udang Indonesia, antara lain:

\section{Kuantitas tenaga kerja}

Jumlah petambak dan nelayan tangkap udang indonesia mencapai 2.216.119 baik pekerja milik sendiri maupun bayaran (BPS, 2013). Tingginya jumlah tenaga kerja yang dimiliki mampu dijadikan sebagai kekuatan karena pelaku utama dalam usahatani adalah tenaga kerja. Namun, disis lain SDM yang dimiliki tersebut masih rendah yang berpengaruh terhadap cara budidaya serta kualitas udang yang dihasilkan (Prayoto, 2004).

\section{Potensi lahan Indonesia}

Saat ini, luas lahan yang berpotensi dilakukan usahatani udang mencapai 2.963.717 Ha, namun yang dimanfaatkan hanya mencapai 657.346 (Ditjen Perikanan). Uji coba telah dilakukan dibeberapa provinsi seperti sumatera utara, sumatera selatan, jawa barat, riau dan beberapa provinsi dan hasil membuktikan bahwa provinsi tersebut memiliki 
potensi untuk dikembangkan budidaya udang (Garno, 2004).

\section{System SSCRC}

\section{Sustainable}

Shrimp/Coastal
Restoration and Conservation (SSCRC) merupakan program pengembangan komoditas udang yang difasilitasi oleh wetkands internation Indonesia program dan IUCN Netherlands. Program tersebut dilakukan untuk memperbaiki hubungan antara Indonesia dengan negara pengimpor udang Indonesia. Tujuan tersebut dapat dicapai oleh SSCRC melalui beberapa program, antara lain:

1) Program penyelenggaraan pengelolaan budidaya terbaik (Better Management Practice) oleh para produsen udang Indonesia.

2) Restorsi mangrove dan pesisir.

3) Sertifikasi komoditas udang yang dikaitkan dengan kontrak-kontrak pembelian internasional.

4) Pengelolaan wilayah pesirir secara terpadu dan berkelanjutan.

\section{Program Pemerintah melalui}

\section{revitalisasi perikanan}

Udang merupakan salah satu komoditas perikanan yang memberikan kontribusi besar terhadap devisa negara. Tingginya kontribusi yang diberikan menjadikan pemerintah memberikan subsidi berupa teknologi serta pengawasan terhadap para petani udang (Waluyo, 2004) sehingga mampu meningkatkatkan jumlah produksi serta kualitas melalui adanya peralihan cara budidaya dari tradisional menuju intensif.

\section{Produksi udang yang meningkat}

Dasar utama suatu negara melakukan ekspor adalah adanya produksi berlebih. Produksi udang Indonesia mengalami peningkatan pada 5 tahun terakhir (Tabel 3). Peningkatan tersebut diimbangangi dengan adanya peningkatan permintaan ekspor udang oleh negara pengimpor. Negara pengimpor udang Indonesia terbesar antara lain Jepang, Uni Eropa, dan Amerika Serikat. 
Tabel 5 Volume ekspor udang Indonesia terhadap negara tujuan

\begin{tabular}{llrrr}
\hline \multirow{2}{*}{ Tahun } & \multicolumn{4}{c}{ Volume Ekspor } \\
\cline { 2 - 5 } & AS & \multicolumn{1}{c}{ Jepang } & Uni Eropa & Negara Linnya \\
\hline 2008 & 80479 & 39582 & 26825 & 177855 \\
2009 & 63592 & 38528 & 23689 & 58180 \\
2010 & 58277 & 36712 & 13383 & 36720 \\
2011 & 68092 & 36605 & 16315 & 31041 \\
2012 & 72526 & 38541 & 16359 & 33524 \\
\hline
\end{tabular}

Sumber: Kementrian Kelautan dan Perikanan, 2012

\section{Proses usahatani udang}

Tingginya biaya produksi yang harus dikeluarkan oleh para peaku usaha udang serta tingginya resiko yang harus ditanggung menjadikan para petani harus melakukan budidaya secara tradisional karena faktor keterbatasan modal yang dimiliki (Yasin, 2013).

\section{Rendahnya diversifikasi produk dan nilai tambah produk udang Indonesia}

Keterbatasan akses modal yang dimiliki petani mengakibatkan perluasan industri pertanian mengalami perlambatan dikarenakan industri pertanian memerlukan banyak modal. Keterbatasan yang dimiliki menjadikan produsen Indonesia hanya bisa melakukan ekspor udang dalam keadaan segar dan beku serta tidak mampu memperluas pangsa pasar karena kurangnya penganekaragaman produk ekspor (Adam, 2014). Proses pengolahan atau variasi produk udang tidak dilakukan oleh produsen Indonesia, melainkan dilakukan oleh produsen pengimpor udang Indonesia. Rendahnya kegiatan yang dilakukan di dalam negri, berakibat pada rendahnya nilai tambah pada komoditas udang Indonesia.

\section{Lingkungan budidaya udang}

Lingkungan sangat berpengaruh terhadap keberlangsungan proses budidaya. Kondisi ekstrim yang ada saat ini, rendahnya konsentrasi oksigen terlarut serta rendahnya $\mathrm{pH}$ air mampu menurunkan laju metabolisme, serta merubah metamorphosis yang berujung pada kematian pada benih udang (Roessig et al, 2004). Kegiatan pemberian 
pakan yang tidak sesuai dengan anjuran mampu menimbulkan adanya penumpukan limbah yang

menyebabkan mikroba baik aerob maupun anaerob (Garno, 2004) bisa muncul yang mampu menurunkan kualitas lingkungan di lahan budidaya. Jika kualitas yang dimiliki rendah akan berakibat pada rendahnya pathogenesitas yang menyebabkan munculnnya penyakit pada udang (Irianto, 2001). Untuk menganggulangi penyakit, produsen udang menggunakan antibiotik. Namun, penggunaan antibiotik tersebut berakibat pada penurunan kualitas udang yang berujung pada penolakan oleh negara pengimpor.

9. Bahan baku pakan masih impor

Pakan memiliki pengaruh terhadap pertumbuhan dan perkembangan udang, sumber energi, dan reproduksi (Bokau, 2008). Terdapat beberapa komposisi bahan yang dilakukan impor dari negara lain. Tepung ikan dan dedak gandum (Pollard) merupakan 2 komposisi bahan baku terpenting sebagai sumber protein hewani dan sedikit kalium yang diimpor dari negara asing. Untuk bahan baku tepung ikan diimpor dari Amerika, Meksiko, dan Thailand. Sedangkan dedak gandum (Pollard) diimpor dari Australia dan Amerika. Dalam melakukan budidaya udang, $60 \%$ dari total biaya dialokasikan untuk membeli pakan. Hal tersebut berdampak pada tingginya harga jual udang yang berpengaruh terhadap tingkat daya saing komoditas udang di pasar internasional.

\section{Kurangnya benih udang di Indonesia}

Ketersediaan benih yang ada saat ini hanya mencapai 2,4 milyar ekor, umlah tersebut masih kurang sehngga perlu dilakukan percepatan produksi untuk memenuhi kebutuhan benih udang dalam negeri (Direktorat Jendral Perikanan, 2012). Keterbatasan yang dimiliki dalam hal pembudidayaan menjadikan negara Indonesia mengalami kekurangan benih udang. Pengembangan usaha perikanan udang bergantung pada ketersediaan induk dan benih unggul karena kedua faktor tersebut tidak dapat dihilangkan dalam melakukan kegiatan produksi udang. 


\section{Permintaan ekspor udang Indonesia oleh negara pengimpor}

Peningkatan jumlah permintaan negara pengimpor sebagai akibat dari adanya peralihan konsumsi masyarakat negara lain dari from red meat to white meat (dari daging merah ke daging putih) yang memberikan peluang bagi produsen indonesia. Namun, pada beberapa tahun terakhir, terjadi penurunan permintaan karena adanya standart dari negara pengimpor serta kandungan antibiotik dan bahan kimia lain yang ada pada udang indonesia. GDP suatu negara juga mempengaruhi tingkat permintaan suatu negara.

Tabel 6. GDP negara pengimpor udang Indonesia dan volume ekspor negara tujuan ekspor udang Indonesia

\begin{tabular}{llll}
\hline \multirow{2}{*}{ Tahun } & \multicolumn{2}{l}{ Negara Tujuan Ekspor } & \\
\cline { 2 - 3 } & Amerika Serikat & Jepang & Uni Eropa \\
\hline $\mathbf{2 0 1 0}$ & 43232,45 & 34822,15 & 28125,51 \\
GDP (U\$) & 58277,00 & 36712,00 & 13383,00 \\
$\quad$ Volume (Ton) & & \\
$\mathbf{2 0 1 1}$ & 43952,44 & 36472,85 & 28631,00 \\
$\quad$ GDP (U\$) & 68092,00 & 36605,00 & 16315,00 \\
$\quad$ Volume (Ton & & \\
$\mathbf{2 0 1 2}$ & 44440,16 & 36203,43 & 29021,86 \\
GDP (U\$) & 72526,00 & 36605,00 & 33580,00 \\
\multicolumn{2}{l}{ Volume (ton) } & \multicolumn{3}{l}{ Sumber: Kementrian Kelautan dan Perikanan, 2012 }
\end{tabular}

\section{Harga udang}

Harga komoditas udang merupakan salah satu faktor yang mempengaruhi tingkat kompetisi ekspor udang. Namun, harga udang dunia juga berkaitan dengan harga komoditas seperti harga subtitusi atau komplementer. Indonesia merupakan negara pengekspor komoditas udang yang bertindak sebagai penerima harga (price taker) udang di pasar internasional. Harga udang dipasar internasional bergerak stabil, hal ini dipengaruhi oleh kurs mata uang dollar yang reatif stabil dikarenakan nilai tukar merupakan salah satu faktor terpenting yang mampu mempengaruhi ekspor (Dollatti et al, 2012). 


\section{Pesaing udang Indonesia}

Negara pengekspor komoditas udang di dunia beragam dengan
Vietnam, Cina, dan Thailand merupakan negara pesaing Indonesia. Vietnam merupakan salah satu negara pesaing ekspor udang dengan harga yang kompetitif. Harga yag ditawarkan oleh negara Vietnam lebih rendah jika dibandingkan dengan harga pasar dunia yang diterima oleh negara Indonesia. Pesaing berat antar negara produsen di pasar internasional menyebabkan perlunya strategi yang dilakukan oleh produsen Indonesia untuk tetap bertahan melakukan ekspor komoditas udang.

\section{Standar yang ditentukan negara pengimpor}

Setiap negara pengimpor memiliki standart masing-masing untuk melindungi konsumen di negara tersebut. Uni Eropa merupakan salah satu negara pengimpor udang Indonesia yang menetapkan kebijakan bahwa negara akan melakukan penolakan terhadap produk yang menggunakan antibiotik, sedangkan produsen udang Indonesia dalam melakukan usahatani menggunakan antibiotik sebagai solusi untuk menurunkan risiko dalam penanganan penyakit yang terjadi pada akuakultur. Standar yang bersifat voluntir (Voluntiry standards), kajian keselarasan (comformance assessment), serta sanitary and phytosanitary (SPS) agreement dilakukan oleh negara pengimpor untuk melindungi kesehatan dan kehidupan manusia, binatang, dan tumbuhan dari wabah penyakit, serta kontaminan negara asing (Nugroho, 2007). Kebijakan ini menjadi restriksi bagi perdangan ekspor, khususnya ekspor udang.

\section{Strategi Peningkatan Daya} Saing Komoditas Udang

\section{Indonesia}

Terdapat beberapa faktor yang mampu mempengaruhi tinggi rendahnya daya saing komoditas udang Indonesia. Faktor-faktor tersebut terdiri dari faktor internal (IFE) yang meliputi kekuatan dan kelemahan, serta faktor eksternal (EFE). Yang terdiri dari peluang dan ancaman.faktor tersebut dilakukan analisis melalui analisis SWOT untuk menentukan strategi melalui matriks 
IFE dan IFE, Diagram SWOT, dan penentuan strategi SWOT.

\section{Matriks IFE dan EFE}

\section{a. Matriks IFE}

Adapun skor yang diperoleh masing-masing faktor berbeda-beda (Tabel 7)

Tabel 7 Matriks IFE daya saing komoditas ekspor udang indonesia

\begin{tabular}{|c|c|c|c|c|}
\hline No & Uraian & Bobot & Rating & Skor \\
\hline & \multicolumn{4}{|l|}{ Kekuatan } \\
\hline 1 & Kuantitas tenaga kerja yang memadai & 0,093 & 3,5 & 0,32 \\
\hline 2 & $\begin{array}{l}\text { Kawasan indonesia memiliki lahan yang } \\
\text { berpotensi untuk budidaya udang }\end{array}$ & 0,093 & 2,75 & 0,25 \\
\hline 3 & $\begin{array}{l}\text { Adanya system SSCRC yang difasilitasi oleh } \\
\text { wetkands internation Indonesia programe dan } \\
\text { IUCN Netherlands }\end{array}$ & 0,092 & 2,25 & 0,21 \\
\hline 4 & $\begin{array}{l}\text { Adanya dukungan pemerintah melalui } \\
\text { program revitalisasi perikanan }\end{array}$ & 0,095 & 2,75 & 0,26 \\
\hline \multirow[t]{3}{*}{5} & Produksi udang terus meningkat & 0,099 & 3,75 & 0,37 \\
\hline & TOTAL & & & 1,42 \\
\hline & \multicolumn{4}{|l|}{ Kelemahan } \\
\hline 1 & Usahatani udang dilakukan secara tradisional & 0.087 & -2 & $-0,17$ \\
\hline 2 & $\begin{array}{l}\text { Rendahnya diversifikasi produk dan nilai } \\
\text { tambah produk udang }\end{array}$ & 0.088 & $-2,75$ & $-0,24$ \\
\hline 3 & Kondisi cuaca yang kurang mendukung & 0.087 & $-2,25$ & $-0,20$ \\
\hline 4 & $\begin{array}{l}\text { Rendahnya kualitas sumber daya manusia } \\
\text { (SDM) }\end{array}$ & 0.085 & $-2,25$ & $-0,19$ \\
\hline 5 & Bahan baku pakan masih impor & 0.097 & -2 & 0,19 \\
\hline 6 & $\begin{array}{l}\text { Rendahnya ketersediaan benih udang di } \\
\text { Indonesia }\end{array}$ & 0.084 & -3 & $-0,25$ \\
\hline & TOTAL & $\mathbf{1 , 0 0}$ & & $-1,25$ \\
\hline
\end{tabular}

Pada matriks IFE, kekuatan terbesar yang mempengaruhi daya saing ekspor udang Indonesia adalah produski udang Indonesia (37\%) mengingat dasar utama suatu negara melakukan ekspor adalah adanya produksi berlebih. Sedangkan kekuatan terendah terletak pada sistem SSCRC (21\%). Permulaan yang baru dari diberlakukannya sistem membuat dampak yang ditimbulkan belum signifikan.

Skor keseluruhan untuk kekuatan adalah 1,42 sedangkan skor untuk kelemahan adalah -1,25. Kelemahan 
terbesar yang dimiliki oleh udang Indonesia yaitu kurangnya benih udang (25\%) karena tidak semua

sentra produksi udang mampu melakukan pembenihan, dan kelemahan terkecil ada pada proses produksi yang masih tradional (17\%) karena berdampak pada kualitas serta jumlah produksi yang akan diperoleh.

\section{b. Matriks EFE}

Pada tabel EFE, peluang daya saing ekspor udang terletak pada tingginya permintaan ekspor udang Indonesia oleh negara pengimpor (37\%) di pasar dunia. Pangsa pasar tebesar ekspr udang Indonesia adalah Jepng, Uni Eropa, dan Amerika. Sedangkan peuang terkecil terletak pada peralihan cara budidaya para petani dan nelayan udang (23\%) mengingat masih banyak para pelaku budidaya udang masih menggunakan proses tradisional. Secara keseluruhan, skor untuk peluang mencapai 1,53 .

Tabel 8 Matriks IFAS daya saing ekspor komoditas udang Indonesia

\begin{tabular}{|c|c|c|c|c|}
\hline No & Uraian & Bobot & Rating & Skor \\
\hline & Peluang & & & \\
\hline 1 & $\begin{array}{l}\text { Permintaan ekspor udang Indonesia mengalami } \\
\text { peningkatan }\end{array}$ & 0,099 & 3,75 & 0,37 \\
\hline 2 & $\begin{array}{l}\text { Usahatani udang dinilai sangat menguntungkan dan } \\
\text { memiliki potensi ekspor yang tinggi }\end{array}$ & 0,095 & 3,75 & 0,36 \\
\hline 3 & $\begin{array}{l}\text { Adanya peralihan selera konsumen from red meat to } \\
\text { white meat }\end{array}$ & 0,090 & 3,25 & 0,29 \\
\hline 4 & Adanya peralihan cara budidaya tradional ke intensif & 0,090 & 2,5 & 0,23 \\
\hline \multirow[t]{3}{*}{5} & Harga udang dunia yang stabil & 0,095 & 3 & 0,28 \\
\hline & TOTAL & & & $\mathbf{1 , 5 3}$ \\
\hline & Ancaman & & & \\
\hline 1 & Banyaknya pesaing udang dari negara lain & 0,093 & -2 & $-0,19$ \\
\hline 2 & Standart yang ditentukan oleh Negara pengimpor & 0,095 & $-1,5$ & $-0,14$ \\
\hline 3 & $\begin{array}{l}\text { Nilai ekspor bergantung pada permintaan udang } \\
\text { Negara pengimpor }\end{array}$ & 0,080 & $-1,5$ & $-0,12$ \\
\hline 4 & Kualitas lingkungan dan air yang menurun & 0,089 & $-2,75$ & $-0,24$ \\
\hline 5 & Adanya penyakit pada udang & 0,092 & $-2,75$ & $-0,25$ \\
\hline \multirow[t]{2}{*}{6} & $\begin{array}{l}\text { Hilangnya mangrove sebagai perlindungan } \\
\text { ekosistem perikanan }\end{array}$ & 0,083 & $-3,5$ & $-0,29$ \\
\hline & TOTAL & 1,00 & & $-1,24$ \\
\hline
\end{tabular}


Untuk ancaman terbesar terletak pada hilangnya mangrove sebagai perlindungan ekosistem perikanan (29\%) yang akan berdampak pada kerusakan lingkungan yang menyebabkan adanya penurunan produksi udang serta kualitas yang semakin menurun. Sedangkan ancaman terkecil terdapat pada nilai ekspor udang bergantung pada permintaan negara pengimpor terhadap udang Indonesia (12\%). Secara keseluruhan, skor ancaman terhadap daya saing ekspor udang mencapai -1,24.

\section{Diagram SWOT}

Diagram SWOT merupakan bentuk perpaduan antara garis horizontal dan vertikal yang saling bertemu membentuk keseimbangan. Pada diagram SWOT, garis horizontal atau sumbu $\mathrm{x}$ diletakkan faktor internal yaitu kekuatan (sumbu $\mathrm{x}$ positif) dan kelemahan (sumbu $\mathrm{x}$ negatif). Sedangkan garis vertikal atau sumbu y diletakkan faktor eksternal yaitu peluang (sumbu y positif) dan ancaman (sumbu y negatif). Nilai masing-masing faktor ialah 1,42 untuk kekuatan yang menempati sumbu $\mathrm{x}$ positif, $-1,25$ untuk kelemahan yang menempati sumbu x negatif, 1,53 untuk peluang yang menempati sumbu y positif, dan $-1,24$ untuk ancaman yang menempati sumbu y negatif.

Keempat nilai tersebut akan membentuk sebuah titik koordinat atau pertemuan empat sumbu yaitu kekuatan dan peluang (sel 1), kekuatan dan ancaman (sel 2), peluang dan kelemahan (sel 3), serta kelemahan dan ancaman (sel 4). Ketika nilai masing-masing sumbu sudah terbentuk, maka masingmasing sumbu akan ditarik garis horintal dan vertikal sehingga masing-masing sumbu bertemu, kemuadian ditarik dua garis linier yang akan membntuk sebuah titik koordinat (5) dimana titik kooerdinat tersebut merupakan penekanan straegi untuk meningkatkan daya saing komoditas udang Indonesia. 


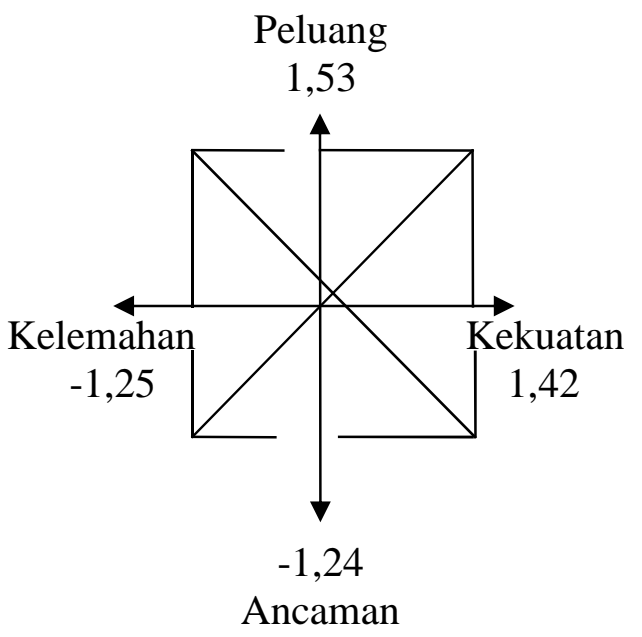

Gambar 5.1 Diagram swot daya saing ekspor komoditas udang Indonesia

Pada diagram SWOT, diperoleh titik 5 yang berada diantara kekuatan dan peluang (sel 1) atau kuadran agresif strategi, artinya dengan kekuatan yang dimiliki, tingkat daya saing komoditas udang Indonesia dapat ditingkatkan melalui pemanfaatan peluang yang dimiliki.

\section{Strategi SWOT}

\section{1) Meningkatkan jumlah produksi udang}

Adanya peralihan cara konsumsi masyarakat luar from red meat to white meat mampu memberikan peluang bagi indonesia untuk meningkatkan jumlah produksi guna memenuhi permintaan pasar dunia yang semakin meningkat. Untuk memenuhi permintaan pasar dunia, perlu adanya peningkatan jumlah produksi karena saat ini indonesia baru bisa memenuhi sekitar 10,8 persen dari permintaan pasar dunia (5.1) dengan cara melakukan budidaya secara intensif dengan menggunakan teknologi-teknologi baru yang telah maju.

\section{2) Memperluas pangsa pasar}

\section{ekspor udang Indonesia}

Saat ini, pangsa pasar terbesar ekspor komoditas udang Indonesia masih berada pada tiga negara. Namun, peluang untuk ekspor masih dimiliki oleh komoditas udang Indonesia. Beberapa negara pengimpor yang hanya menginginkan udang Indonesia bukan udang lain. fakta tersebut mampu dijadikan peluang bagi Indonesia untuk meningkatkan volume dan nilai ekspor. Tepatnya informasi yang diterima oleh konsumen adalah hal yang sangat penting karena akan berpengaruh terhadap pengetahuan konsumen terhadap produk impor. Suatu negara yang memutuskan memasuki pasar global diperlukan alternatif-alternatif memperluas pangsa pasar yang dimulai dengan perencanaan pemasaran. 


\section{3) Meningkatkan kualitas udang Indonesia}

Standar yang ditentukan oleh negara pengimpor merupakan sebuah tuntutan yang harus dipenuhi oleh negara pengekspor (Indonesia). Penggunaan antibiotik pada komoditas udang merupakan salah satu penyebab ditolaknya ekspor komoditas udang Indonesia oleh negara pengimpor. Penggunaan serta inovasi terhadap teknologi mampu dijadikan sebagai salah satu alternatif untuk meningkatkan kualitas udang Indonesia.

\section{4) Menggunakan teknologi tepat guna sebagai upaya dalam meningkatkan budidaya secara intensif}

Ketepatan dalam melakukan usahatani udang Indonesia berpengaruh terhadap kuantitas dan kualitas udang Indonesia. peralihan Budidaya udang secara intensif dapat dikategorikan sebagai budidaya dengan padat modal karena cara budidaya yang berbeda yaitu menggunakan teknologi yang modern serta pakan yang menggunakan tinggi kandungan protein. Cara budidaya secara intensif secara polikultur dianggap mampu menghilangkan penyakit white spot pada udang sehingga mampu mempertahankan tingkat produksi udang untuk memenuhi permintaan ekspor.

produk ekspor komoditas
udang

Pola diversifikasi produk mampu meningkatkan perluasan pasar karena banyaknya keanekaragaman produk ekspor yang dapat dipilih oleh konsumen negara pengimpor. Ekspor beragam produk mampu dilakukan oleh negara pengekspor jika suatu negara mampu menyediakan banyak dana serta teknologi yang tepat guna. Fenomena pemasaran produk ikan yang terus berkembang mampu menunjukkan adanya potensi yang dimiliki oleh komoditas perikanan termasuk udang. Sector agribisnis merupakan sector yang memliki peranan penting dalam pembangunan sektor industri melalui adanya diversifikasi produk.

\section{6) Melakukan inovasi teknologi \\ Rekayasa teknologi merupakan salah satu cara yang bisa dilakukan untuk mengurangi resiko yang terjadi pada usahatani udang. Kondisi cuaca}


yang tidak menentu dapat dilakukan upaya pencegahan dengan cara melakukan inovasi terhadap teknologi merupakan salah satu aplikasi inovasi teknologi yang bisa digunakan untuk meminimalisir terjadinya dampak buruk terhadap komoditas udang.

7) Memperbaiki sistem pengairan disekitar lingkungan budidaya udang

Terdapat banyak kerugiaan dan ancaman terhadap kelestarian lingkungan yang ditimbulkan oleh pencemaran lingkungan. Untuk mengembalikan kualitas lingkungan dapat dilakukan beberapa hal, antara lain:

a. Menambah tanaman hijau (reboisasi) untuk mencegah adanya pencemaran sejak dini

b. Melakukan penurunan suhu terhadap gas buangan sebelum dibebaskan ke air yang menyebabkan menurunnya kualitas air

c. Dilakukan pengawasan terhadap penggunaan pestisida, insektisida, dan bahan kimia lainnya yang mampu menjadi pemicu terjadinya

pencemaran

lingkungan.

d. Melakukan

pencegahan

\section{terhadap penyakit udang}

Udang sangat rentan terhadap serangan penyakit yang disebabkan oleh parasit, jamur, protozoa, bakteri dan virus (Astuti, 2009). Penggunaan antibiotik merupakan cara untuk mencegah penyakit. Namun mampu menurunkan kualitas udang dikarenakan adanya penolakan pada komoditas udang yang menggunakan antibiotik. Whole Cell Killed Virus (WCKV) merupakan vaksin yang bisa digunakan untuk mematikan serangan bakteri yang mnyerang pada udang. Udang yang diberi vaksin WCKV dapat digolongkan udang yang sehat karena memiliki kekebalan tubuh yang lebih serta mampu melindungi diri terhadap keganasan serangan virus (Johnson, 2008).

\section{PENUTUP}

\section{Kesimpulan}

Berdasarkan hasil penelitian, maka dapat disimpulkan: (1) udang Indonesia daya saing ekspor yang kuat ditunjukkan dengan nilai RCA $>1$, dan terjadi peningkatan 
kinerja antara tahun sekarang dengan tahun sebelumnya ditunjukkan adanya indeks RCA $>1$, (2) faktorfaktor yang mempengaruhi tersebut ialah tenaga kerja, lahan, progrm pemerintah, jumlah produksi, modal, diversifikasi produk, lingkungan, sdm, bhaan baku, benih, permintaan, harga, pesaing, standart dan kualitas, dan (3) strategi yang diambil untuk meningkatkan daya saing ekspor udng ditekankan dengan cara meningkatkan jumlah produksi untuk memenuhi permintaan ekspor dari negara lain.

\section{Saran}

Berdasarkan hasil penelitian, terdapat beberapa saran yang diajukan oleh penulis untuk meningkatkan daya saing ekspor udang Indonesia, antara lain (1) memperluas pangsa pasar ekspor udang indonesia dengan menambah partner kerja pemasaran dengan negara lain di dunia, (2) perlu adanya peningkatan jumlah produksi, perbaikan sarana dan prasarana produksi untuk meningkatkan nilai ekspor komoditas udang dalam memenuhi permintaan udang di pasar internasional, dan (3) mengkatkan kualitas udang indonesia sesuai dengan standart yang ditentukan oleh negara pengimpor.

\section{DAFTAR PUSTAKA}

Adam, K, P, Adi. 2014. Industri Ekspor Udang Indonesia. http://www.digilib.ui.ac.id/op ac/themes/libri2/detail.jsp?id $=90672$. Diakses 01 Desember 2014.

Apridar. 2009. Ekonomi Internasional: Sejarah, Teori, Konsep dan Permasalahan dalam Aplikasinya. Yogyakarta: Graha Ilmu.

Astuti, S.M. 2009. Penyakit Parasiter pada Udang. http://www.tambak.org. Diakses 24 Agustus 2014.

Bokau, J.M.R., Wamiliana, Sutikno. 2008. Pemodelan Program Linier untuk Optimasi Agroindustri Pakan Udang. $J$. Sains MIPA, Edisi Khusus Thun 2008, Vol. 14, No. 1, Hal: 59-64 ISSN: 1978-1873.

BPS. 2012. Produk Domestik Bruto Tahun 2000 Hingga 2012 Negara Indonesia. http://www.bps.go.id/tab_sub/ view.php?kat $=2 \&$ tabel $=1 \& d$ aftar $=1 \& i d$ subyek $=11$ \&not $\underline{a b=3}$ Diakses 15 Agustus 2014.

BPS. 2013. Jumlah Petani Indonesia Menurut Sub Sektor dan Jenis Kelamin http://st2013.bps.go.id/dev/st 
2013/index.php/site/tabel?tid

$=23 \&$ wid $=0000000000$.

Diakses 05 Desember 2014.

Direktorat Jendral Perikanan. 2013.

Produksi benih udang berkualitas dukung program revitalisasi tambak. www.djpb.kkp.go.id/berita.ph p?id=938 Diakses 16 Januari 2015.

Direktorat Jendral RI. 2013. Kinerja Ekspor Indonesia Tahun 2013. http://djpen.kemendag.go.id/a pp_frontend/admin/docs/publ ication/9591390367799.pdf. Diakses tanggal 28 Agustus 2014.

Garno, Y, S. 2004. Penembangan Budidaya Udang dan Potensi Pencemarannya pada Perairan Pesisir. Jurnal Tek.Ling. P3TL-BPPT. Volume 5, No. 3: 187-192.

Irianto, A. 2003. Patologi Ikan Teleostei. Gajdah Mada University Press. Yogyakarta.

Johnson. 2008. Vaccination of Shrimp Against Viral Pathogents: Phenomenology and Underlyfing Mechanism. Vaccine. 26: 4885-4892.

Nugroho, A. 2007. Peran dan Kedudukan Indonesia dalam Peta Diplomasi Pemasaran Produk Ekspor Hasil Perikanan Indonesia di Pasar Internasional. Jakarta: Departemen Perikanan dan Kelautan.
Prayoto. 2004. Menyoal Kualitas Sumber Daya Manusia Indonesia. Majalah Ilmiah UNIKOM Vol. 01, Januari 2004.

Roessig, M. Julie, Woodley, M. C, Cech, J. J, Hansen, J. L. 2004. Efeects of Global Climate Change on Marine and Estuarine Fishes and Fisheries. Reviews in Fish Biology and Fsheries 14: 251275.

Waluyo, A. 2014. Mensejahterakan Petani. http://www.wikipedia.org/php . diakses pada Agustus 2014.

Yasin, Muhammad. 2013. Prospek Usaha Budidaya Udang Organik Secara Polikultur. Jurnal Ilmiah Agriba No. 1. Edisi Maret Tahun 2013. ISSN: 2303-1158. 